\title{
ANALISIS DERAJAT DESENTRALISASI FISKAL KOTA MALANG TAHUN 2004-2008
}

\author{
Oleh: \\ Andarini Agus Tiyaningsih \\ Staff PT. Sicha Jaya Sentosa Malang \\ E-mail/No. Hp: Andacome@yahoo.co.id /08563615644
}

\begin{abstract}
The purpose of my research is to find desentralisasi degree fiscal of Malang city 2004-2008 years old. The analysis tools is desentralisasi degree fiscal include Ratio Pendapatan Asi Daerah (PAD) with Total Penerimaan Daerah (TPD), ratio Bagi Hasil Pajak dan Bukan Pajak (BHPBP) with Total Penerimaan Daerah (TPD) and ratio Sumabngan Daerah (SD) with Total Penerimaan Daerah (TPD). The result of ratio analysis PAD with TPD are 13,05\%, the result of ratio analysis BHPBP with TPD are $9,00 \%$ and the result of ratio analysis SD withTPD are 8,94\%. Such was the case the result of that analysis is Malang was not independent, because the biggest fund of central goverentment, and Pendapatan Asli Daerah (PAD) of Malang is low.
\end{abstract}

Keywords: $P A D, B H P B, S D$, and $T P D$

\section{PENDAHULUAN}

Desentralisasi fiskal pada akhirakhir ini menjadi isu yang hangat di seluruh dunia. Pemerintahan pusat baik di Negara maju maupun Negara berkembangtelah mencoba untuk mendelegasikan tanggung jawab, otoritas, dan sumber daya yang terkait (keuangan, pegawai, peralatan, dan lainlain) kepada tingkatan pemerintah yang lebih rendah. Motivasi dibalik semua inisiatif ini adalah untuk lebih baik dan logis untuk membuat keputusan kepada institusi atau masyarakat yang secara langsung akan merasakan dampak dari kebijakan yang akan dibuat oleh pemerintah.

Sejak proklamasi kemerdekaan Republik Indonesia, kebijakan desentralisasi telah mengalami beberapa kali perubahan yang ditandai dengan pasang surutnya derajat desentralisasi, namun pasca reformasi ini telah memperlihatkan komitmen yang kuat untuk melaksanakan desentralisasi keuangan. Perubahan kebijakan desentralisasi ini menandai pula arah pendahulu yang sering kali berubah antara structural efficiency model dan local democracy model. Era reformasi menuju local democracy model sesuai semangat yang dimaksudkan dalam UU nomor 22 tahun 1999 tentang pemerintahan daerah. UU tersebut telah diganti dengan nomor 32 tahun 2004 tentang desentralisai yang berusaha mempertemukan semangat efisiensi dan demokrasi.

Undang-Undang nomor 22 tahun 1999 tentang Pemerintahn Daerah dan Undang-Undang nomor 25 tahun 1999 tentang Perimbangan Keuaangan Pusat dan Daerah, masing-masing telah diperbaharui dengan Undang-Undang nomor 32 taun 2004 dan UndangUndang nomor 33 tahun 2004. dalam hal ini model pemerintahan telah berubah dari pemerintahan yang tersentralisasi menjadi model pembangunan yang terdesentralisasi. Pergerakan ini bertujuan untuk mempromosikan otonomi daerah, transparansi 
pemerintah, efisiensi dan efektifitas ekonomi, serta keadilan dalam menikmati layanan publik.

Undang-Undang nomor 32 tahun 2004 pada intinya adalah memberikan kewenangan di daerah untuk mengatur semua urusan pemerintahan kecuali pada bidang politik luar negeri, pertahanan dan keamanan, peradilan, moneter dan fiskal serta agama. Sejalan dengan itu, maka terjadi perubahan paradigma tata pemerintahn dari sentralisasi dimana peran pemerintah pusat sangat dominan, menjadi desentralisasi dimana peran pemerintah pusat menjadi terbatas, tidak mendominasi dalam perumusan dan keputusan kebijakan pemerintah di daerah.

Adanya desentralisasi fiskal, pemerintah bermaksud untuk memperbaiki perencanaan dan implementasi dalam penyediaan barang dan pelayanan publik sesuai dengan kondisi dan preferensi daerah dengan tetap berpedoman pada tujuan pembangunan sosial dan ekonomi baik di tingkat pemerintahan pusat maupun pemerintahan daerah.

Menurut Rondinelli (1990) dalam Khairul (2007:13) Desentralisasi dan demokrasi tidak saling meniadakan tetapi juga tidak terkait, keduanya adalah konsep yang berbeda. Di dalam pemerintahan yang sangat sentralistis bisa saja terjadi demokrasi apabila pejabatnya dipilih secara berkala oleh rakyatnya. Desentralisasi administratifpun dapat dipergunkan untuk melakukan kontrol negara atas unit-unit wilayahnya guna meningkatkan partisipasi politik yang lebih besar dalam pembuatan keputusan.

Sedangkan menurut Smith (1985:11) dalam Khairul (2007:11) menjelaskan bahwa desentralisasi diasumsikan memerlukan demokrasi. Meskipun desentralisasi tidak membawa implikasi terhadap demokrasi, tetapi desentralisasi untuk mencapai tujuan yang di kehendaki tetap memerlukan adanya demokrasi.

Demokrasi liberal memberikan dukungan bagi desentralisasi karena mampu mendukung demokrasi, Khairul (2007:2) menjelaskan desentralisasi memberikan kontribusi yang positif bagi demokrasi nasional, karena Pemerintahan Daerah mampu menjadi saarana pendidikan politik, serta mendukung penciptaan stabilitas politik. Lebih jelas menurut Hoessein (2000) dalam Khairul (2007:2) menambahkan bahwa dalam konsep otonomi terkandung kebebasan untuk berprakarsa dalam mengambil keputusan atas dasar aspirasi masyarakat yang memiliki status demikian tanpa kontrol langsung oleh Pemerintah Pusat.

Desentralisasi dalam konteks proses demokratisasi perlu dipahami sebagai instrumen pengambilan keputusan dalam kebijakan dalam kebijakan publik yang lebih demokratis yang mengandung implikasi luas tehadap aspek sosial, politik dan ekonomi, di mana terdapat hubungan antara aspek satu dengan aspek lainnya. Oleh sebab itu, penerapan desentralisasi diwujudkan dalam bentuk desentralisasi politik, admistratif, fiskal dan ekonomi.

Pada dasarnya desentralisasi merupakan sebuah keniscayaan bagi penyelenggaraan pemerintah demokratis di negara Indonesia. Kebijakan desentralisasi melahirkan pemerintahan pemerintah daerah yang memiliki polical variety untuk menyalurkan local voice dan local choice. Desentralisasi dimaksudkan sebagai instrumen yang mampu mengakomodasikan aspirasi masyarakat yang tergolong majemuk dengan kondisi dan potensi yng beragam. Namun demikian, perlu untuk diwaspadai dampak negatif desentralisasi yang tidak terkendali, seperti munculnya republik kecil, raja 
kecil, dan sebagainya akibat lemahnya kontrol pusat terhadap daerah.

Semangat desentralisasi pada dasarnya adalah strategi menumbuhkan proses demokratisasi di daerah. Tidak saja dalam bentuk kedaulatn pemerintah daerah yang tidak lagi didominasi oleh pemerintahan pusat, tetapi juga menumbuhkan partisipasi politik yang luas. Partisipasi politik dalam pengertian konvensional, secara nyata telah terlihat dalam praktik pemilihan kepala daerah secara langsung. Partisipasi politik juga perlu di dorong dalam bentuk ikut mempengaruhi kebijakan yang melakukan pengawasan terhadap kinerja pemerintah.

Dalam rangka mendorong demokratisasi dan pembangunan daerah, implementasi desentralisasi tidak dapat dilepaskan dari keempat bentuk desentralisasi tersebut dan tidak dapat membatasi hanya pada satu bentuk desentralisasi.

Keberhasilan desentralisasi menurut Sidik (2002) dalam Pheni (2005:4) setidaknya tergantung pada desain, proses implementasi, dukungan politis pada tingkat pengambian keputusan di semua level pemerintahan dan masyarakat luas, kesiapan administratif pemerintahan, pengembangan kelembagaan dan Sumber Daya Manusia (SDM), mekanisme koordinasi untuk meningkatan kinerja aparat birokrasi, perubahan sistem nilai dan perilaku birokrasi dalam memberikan pelayan kepada masyarkat.

Keberhasilan desentralisasi juga dapat dilihat dari kinerja Pemerintah Daerah. Dengan adanya desentralisasi, pemerintah daerah harus bisa menggunakan segala potensi yang ada di daerah secara optimal seperti: Sumber Daya Manusia (SDM), Sumber Saya Alam (SDA), peningkatan Penerimaan Daerah, Peningkatan Sumber daerah dan lain sebagainya, dan menjadi daerah yang mandiri dengan adanya desentralisasi atau mengurangi ketergantungannya terhadap sumbersumber daerah lain dan juga dari pemerintah pusat.

Dengan adanya desentralisasi fiskal, Pemerintah Daerah harus bisa menggunakan segala potensi yang ada di daerah secara optimal seperti: Sumber Daya Manusia (SDM), Sumber Saya Alam (SDA), Pajak Daerah, Retribusi Daerah dan sebagainya yang diharapkan dapat meningkatkan peningkatan Pendapatan Asli Daerah (PAD) dan sumber-sumber keuangan daerah Kota Malang agar nantinya mampu menjadikan daerah tersebut mandiri secara nyata dan bertanggung jawab atau mengurangi ketergantungannya terhadap sumber-sumber daerah lain dan juga dari pemerintah pusat.

Besarnya bantuan pemerintah bukan berarti daerah Kota Malang kurang memiliki inisiatif untuk menghimpun dana dari penerimaan daerah, karena fakta menunjukkan perkembangan penerimaan Kota Malang sejak tahun 2004 sebesar Rp.339.561.311.285,00, sedangkan pada tahun 2008 meningkat menjadi Rp.708.153.734.493,00 Disamping itu juga sumber-sumber daya alam yang dimiliki oleh daerah Kota Malang harus dimanfaatkan secara optimal sehingga dapat meningkatkan Pendapatan Asli Daerahnya (PAD) yang kemudian akan menjadi daerah yang mandiri. (Sumber: Sekretariat Daerah Kota Malang Bagian Keuangan).

Adapun alasan peneliti melakukan penelitian di Kota Malang adalah potensi yang dimiliki Kota Malang semakin berkembang dengan bertambah lengkapnya sarana dan prasarana yang ada, khususnya sejak adanya otonomi daerah yang diikuti oleh kebijakan desentralisasi fiskal, dengan landasan 
UU Nomor 32 tahun 2004 tentang Pemerintahan Daerah.

\section{TINJAUAN PUSTAKA}

Desentralisasi Fiskal bermula dengan UU No. 32/2004 dan UU No. 33/2004 dimana menyatakan bahwa pemerintah kabupaten/kota berwenang dan bertanggung jawab untuk menyediakan layanan umum yang luas pada hampir semua bidang kehidupan masyarakat. Hal ini mengubah pengelolaan fiskal yang mulanya sentralisasi menjadi desentralisasi.

Menurut Mulyana (2006:26) desentralisasi fiskal merupakan pendelegasian tanggung jawab, otoritas, dan sumber-sumber yang berkaitan (seperti: keuangan, karyawan. Dan lainlain) dari pemerintahan pusat kepada tingkatan pemerintahan yang lebih rendah. Sedangkan menurut Richard (2000:4) desentralisasi fiskal merupakan pelepasan tanggung jawab yang berada dalam lingkungan pemerintah pusat ke instansi vertikal di daerah atau Pemerintah Daerah.

Desentralisasi fiskal dalam arti sempit menurut Smith (1985:18) dalam Khairul (2007:8) berkaitan dengan dua hal. Pertama adanya subdivisi teritori dari suatu negara yang mempunyai ukuran otonomi. Subdivisi teritori memiliki self governing melalui lembaga politik yang memiliki akar dalam wilayah sesuai dengan batas yuridiksinya. Kedua lembaga-lembaga tersebut akan direkrut secara demokratis. Berbagai keputusan akan di ambil berdasarkan prosedur demokratis.

Secara konseptual, menurut Pheni (2005:1) sulit untuk mendapatkan definisi yang tepat untuk mengartikan desentralisasi fiskal, kecuali dengan merujuk pada empat bentuk desentralisasi, yaitu: Desentralisasi politik (political decentralization), Desentralisasi administratif (administrative decentralization), Desentralisasi fiskal (fiscal decentralization), Desentralisasi ekonomi (economic or market decentralization)

Desentralisasi mencakup beberapa makna, yang mencakup hal-hal berikut yaitu distribusi kewenangan dari pusat ke daerah, yang berarti distribusi kewenangan pemerintah pusat dalam bentuk kewenangan dekonsentrasi dan delegasi kewenangan. Yang pertama adalah pemberian kewenangan ke organ pemerintah pusat di daerah dan yang kedua adalah delegasi kewenangan dari pemerintah pusat ke organ lokal. Sebaliknya, devolusi kewenangan berarti perpindahan kewenangan dari pemerintah pusat ke daerah yang disertai dengan realokasi sumber penerimaan dan pembiayaan. Dalam tulisan ini, desentralisasi mengarah pada definisi devolusi.

Desentralisasi fiskal pada dasarnya berkaitan dengan dua hal pokok, yakni kemandirian daerah dalam memutuskan pengeluaran guna menyelenggarakan layanan publik dan pembangunan, dan kemandirian daerah dalam memperoleh pendapatan untuk membiayai pengeluaran tersebut.

Alasan utama penerapan desentralisasi fiskal karena pengambilan keputusan akan lebih baik apabila diserahkan kepada tingkatan yang lebih rendah yang secara langsung dapat merasakan dampak dari program dan pelayanan yang akan direncanakan oleh pemerintah.

Era desentralisasi fiskal memberikan peluang yang sebesarbesarnya kepada Pemerintah Daerah untuk membangun daerah berdasarkan kemampuan dan kehendak daerah sendiri. Peluang seperti ini tidak pernah ada selama Orde Baru, yang terjadi sebaliknya yaitu ketergantungan fiskal dan subsidi serta bantuan Pemerintah 
Pusat sebagai wujud ketidakberdayaan Pendapatan Asli Daerah (PAD) dalam membiayai Belanja Daerah.

Dalam era orde baru, Pemerintah Pusat terlalu dominan terhadap daerah. Pola pendekatan yang sentralistik dan seragam yang selama ini dikembangkan Pemerintah Pusat telah mematikan inisiatif dan kreativitas daerah. Pemerintah daerah kurang diberi keleluasaan untuk menentukan kebijakan daerahnya sendiri. Kewenangan yang selama ini diberikan kepada daerah tidak disertai dengan pemberian infrastruktur yang memadai, penyiapan sumber daya manusia yang profesional. Akibatnya, yang terjadi bukannya tercipta kemandirian daerah, tetapi justru ketergantungan daerah terhadap Pemerintah Pusat.

Dalam pemerintahan yang tersentralisasi semua keputusan dibuat oleh pemerintahan pusat. Maka akan mumncul jurang antara pemerintahan pusat dan rakyatnya. Sebagai akibtanya pemerintah kurang memperhatikan kebutuhan rakyatnya dan barang serta pelayanan publik yang disediakan oleh pemerintah tidak dapat memenuhi keinginan masyarakat.

Untuk mrngurangi sifat sentralisasi ini, menurut Mulyana (2006:27-28) pemerintah dapat melakukan tiga hal yaitu: dekonsentrasi, delegasi, dan desentralisasi fiskal. Dekonsentrasi adalah proses pemindahan kekuasaan dalam pengambilan keputusan (yang masih terkait dengan struktur pemerintah pusat) dari pejabat pemerintah pusat yang ada di tingkat pusat kepada pejabat pemerintah pusat yang berada diluar pemerintah pusat (di tingkat regional/provinsi tau loka). Delegasi merupakan proses pemindahan tanggung jawab pengeluaran dari pemerintahan pusat kepada badan pemerintahan yang semi-autonomous. Desentralisasi fiskal adalah pendistribusian tanggung jawab pengambilan keputusan dan pengelolaan dari tingkatan pemerintahan yang lebih tinggi kepada tingkatan pemerintahan yang lebih rendah.

Menurut Meenakshisundaram (1999:55-56) dalam Muluk (2007:6) untuk mengurangi sifat sentralisasi ini, pemerintah dapat melakukan empat hal, yaitu: Deconcentration, Delegation, Devolution, Privatization. Deconcentration yaitu penyerahan sejumlah kewenangan atau tanggung jawab administrasi kepada tingkatan yang lebih rendah dalam kementrian atau badan pemerintah. Delegation yaitu perpindahan tanggung jawab fungsifungsi tertentu kepada organisasi diluar struktur birokrasi reguler dan hanya dikontrol oleh pemerintahan pusar secara tidak langsung. Devolution yaitu pembentukan dan penguatan unit-unit pemerintahan subnasional dengan aktivitas yang secara subtansial berada diluar kontrol pemerintahan pusat. Privatization yaitu memberikan semua tanggung jawab atas fungsi-fungsi kepada organisasi nonpemerintah atau perusahaan swasta yang independen dari pemerintah. dari definisi di atas, tercermin bahwa pemerintahan lokal memiliki derajat otonom tertentu, dan setiap pemerintah daerah (regional dan lokal) bertanggug jawab terhadap seluruh rakyat daerah yang bersangkutan.

Desentralisasi di ndonesia menurut Pheni (2005:4) diwujudkan dalam kebijakan penting oleh pemerintahan tansisi Habibie dengan dikeluarkannya Undang-Undang Nomor 22 Tahun 1999 tentang Pemerintahan Daerah. UndangUndang tersebut memberikan kewenangan kepada pemerintah daerah untuk mengatur semua urusan pemerintah. Sejalan dengan itu, maka terjadi perubahan paradigma tata pemerintahan dari sentralisasi dimana peran pemerintah pusat sangat dominan, 
menjadi desntralisasi dimana peran pemerintah pusat menjadi terbatas.

Implikasi langsung dari desentralisasi kewenangan kepada pemerintah dearah adalah peningkatan kebutuhan dana yang signifikan bagi daerah. Untuk itu perlu diatur hubungan (perimbangan) keuangan antara Pemerintah dan daerah sedemikian rupa sehingga kebutuhan pnegeluaran yang akan menjadi tanggung jawab yang akan menjadi tanggung jawab daerah dapat dibiayai dari sumber-sumber penerimaan yang ada.

\section{METODE PENELITIAN}

Desentralisasi fiskal merupakan pelepasan tanggung jawab dalam urusan pemerintahan dari pemerintahan pusat kepada pemerintahan daerah Kota Malang yang dilihat dengan rasio Pendapatan Asli Daerah (PAD) dengan Total Penerimaan Daerah (TPD), Bagi Hasil Pajak dan Bukan Pajak (BHPBP) dengan Total Penerimaan Daerah (TPD), Sumbangan Daerah (SD) dengan Total Penerimaan Daerah (TPD).

Untuk melihat kemampuan daerah dalam menjalankan desentralisasi, salah satunya bisa diukur melalui kinerja/kemampuan keuangan daerah dengan beberapa alat analisis Keuangan Daerah.

Berikut ini disampaikan alat analisis Menurut konsep Hikmah (1999) dalam Halim (2004:24), Untuk melihat Derajat desentralisasi fiskal antara pemerintah Pusat dan Daerah yaitu:

1. $\frac{\text { Pendapatan Asli Daerah (PAD) }}{\text { Total Penerimaan Daerah (TPD) }} \times 100 \%$

2. Bagi Hasil Pajak dan Bukan Pajak untuk Daerah (BHPBP) Total Penerimaan Daerah (TPD)

3. $\frac{\text { Sumbangan Daerah (SD) }}{\text { Total Penerimaan Daerah }}$

Dengan $\mathrm{TPD}=\mathrm{PAD}+\mathrm{BHPBP}+\mathrm{SB}$, apabila hasil perhitungan lebih tinggi dari bantuan Pemerintah Pusat, maka desentralisasinya tinggi (mandiri) dan sebaliknya apabila hasil perhitungan lebih rendah dari bantuan Pemerintah Pusat maka desentralisasinya juga rendah (tidak / kurang mandiri).

\section{PEMBAHASAN}

Anggaran Pendapatan dan Belanja Daerah merupakan rencana keuangan tahunan pemerintahan daerah yang dibahas dan disetujui bersama oleh pemrintah daerah dan Dewan Perwakilan Rakyat Daerah (DPRD) dan ditetapkan oleh peraturan daerah.

Realisasi Anggaran Pendapatan Belanja Daerah (APBD) kota Malang pada tahun 2004, Pada sisi penerimaan daerah, yang terdiri dari Pendapatan Asli Daerah (PAD) sebesar Rp. 49.528.288.300,00 yang terdiri dari pajak daerah, retribusi daerah, hasil pnegelolaan kekayaan daerah yang dipisahkan dan lain-lain pendapatan yang sah. Dalam hal ini pajak daerah mempunyai nilai tertinggi yaitu sebesar Rp. 25.648.275.000,00 jika dibandingkan dengan retribusi daerah yang nilainya hanya $\mathrm{Rp}$. 15.811.138.300,00. pajak daerah merupakan nilai yang tertinggi dalam peningkatan Pendapatan Asi Daerah (PAD) karena kota Malang merupakan kota yang banyak mempunyai hotel, restoran dan lain-lain. Adapun pajak daerah Kota Malang diperoleh dari pajak hotel, pajak restoran, pajak reklame, pajak penerangan jalan umum.

Dari sisi Dana Perimbangan, mempunyai nilai sebesar Rp. 277.374.022.985,00 yang terdiri dari bagi hasil pajak, bagi hasil bukan pajak, Dana Alokasi Umum (DAU), dan Dana Alokasi Khusus (DAK). Dana Alokasi Umum (DAU) Kota Malang masih tinggi yaitu sebesar Rp. 211.628.000.0000,00 jika dibandingkan dengan dan Dana Alokasi Khusus 
(DAK) yang nilainya sangat kecil yaitu sebesar Rp. 5.500.000.000,00. Sedangkan transaksi pada Bagi Hasil Pajak atau Bagi Hasil Bukan Pajak (BHPBP) yang mempunyai nilai $\mathrm{Rp}$. 36.040.775.046,00 dan Bagi Hasil Pajak dan Bantuan Keuangan dari Propinsi sebesar Rp. 24.205.247.939,00.

Pada pos belanja daerah, dibedakan menjadi dua, yaitu: Belanja Aparatur daerah dan Belanja Publik. Belanja aparatur daerah terdiri dari belanja administrasi umum sebesar Rp. 80.728.594.070,73, belanja operasi dan pemeliharaan sebesar Rp. 11.673.163.700,00, belanja modal sebesar Rp. 4.638.941.500,00. Sedangkan Belanja Publik terdiri dari: belanja administrasi umum sebesar Rp. 155.831.235.272,00, belanja operasi dan pemeliharaan sebesar Rp. 57.294.568.864,00, belanja modal sebesar Rp. 40.370.838.090,00 dan belanja bagi hasil dan bantuan keuangan sebesar Rp. 25.722.449.400,00, serta belanja tidak tersangka sebesar Rp. 2.621.873.534,73.

Dari rincian Anggaran Pendapatan Belanja Daerah (APBD) kota Malang pada tahun 2004 mengalami defisit, sebesar Rp. 39.320.353.249,73 karena jumlah belanja lebih besar yaitu $\mathrm{Rp}$. 378.881.664.534,73 jika dibandingkan dengan jumlah pendapatan $\mathrm{Rp}$. 339.561.311.285,00. Oleh karena itu, Pemerintah Kota Malang harus lebih meningkatkan pendapatan daerahnya agar Anggaran Pendapatan dan Belanja Daerah (APBD) tidak defisit.

Realisasi Anggaran Pendapatan Belanja Daerah (APBD) kota Malang pada tahun 2005, Pada sisi penerimaan daerah yang terdiri dari Pendapatan Asli Daerah (PAD) Kota Malang sebesar Rp. 60.064.915.500,00, meningkat dari tahun 2004, yang terdiri dari pajak daerah, retribusi daerah, hasil pnegelolaan kekayaan daerah yang dipisahkan dan lain-lain pendapatan yang sah. Dalam hal ini pajak daerah mempunyai nilai tertinggi yaitu sebesar Rp. 29.512.487.500,00, yang meningkat dari tahun 2004. Retribusi daerah sebesar Rp. 17.060.726.000,00. pajak daerah merupakan nilai yang tertinggi dalam peningkatan Pendapatan Asi Daerah (PAD) karena kota Malang merupakan kota yang banyak mempunyai hotel, restoran dan lain-lain. Adapun pajak daerah Kota Malang diperoleh dari pajak hotel, pajak restoran, pajak reklame, pajak penerangan jalan umum. Sedangkan nilai dari hasil perusahaan daerah sebesar Rp. 6.154.202.000,00 dan lain-lain pendapatan asli daerah yang sah sebesar Rp. 7.337.500.000,00

Dari sisi Dana Perimbangan, mempunyai nilai sebesar Rp. 310.022.356.552,00 yang terdiri dari bagi hasil pajak, bagi hasil bukan pajak, Dana Alokasi Umum (DAU), dan Dana Alokasi Khusus (DAK). Dana Alokasi Umum (DAU) Kota Malang masih tinggi yaitu sebesar Rp. 211.130.000.000,00 jika dibandingkan dengan dan Dana Alokasi Khusus (DAK) yang nilainya sangat kecil yaitu sebesar Rp. 7.780.000.000,00. Sedangkan transaksi pada Bagi Hasil Pajak atau Bagi Hasil Bukan Pajak (BHPBP) yang mempunyai nilai $\mathrm{Rp}$. 43.500.724.802,00 dan Bagi Hasil Pajak dan Bantuan Keuangan dari Propinsi sebesar Rp. 37.611.631.750,00.

Pada pos belanja daerah dibedakan menjadi dua, yaitu: Belanja Aparatur daerah dan Belanja Publik. Belanja aparatur daerah terdiri dari belanja administrasi umum sebesar Rp. 113.899.146.153,20, belanja operasi dan pemeliharaan sebesar Rp. 11.665.953.400,00, belanja modal sebesar Rp. 2.455.920.000,00. Sedangkan Belanja Publik terdiri dari: belanja administrasi umum sebesar Rp. 132.875.078.458,64, belanja operasi dan 
$\begin{array}{lcr}\text { pemeliharaan } & \text { sebesar } & \mathrm{Rp} . \\ 69.357 .914 .028,00, & \text { belanja } & \text { modal }\end{array}$ sebesar Rp. 67.726.745.050,00 yang meningkat dari tahun 2004, karena pada tahun 2005 ini ada penambahan Belanja Modal Barang Bercorak Kesenian dan Kebudayaan dan Belanja Modal Hewan, Ternak serta Tanaman yang pada tahun 2004 tidak ada. Belanja bagi hasil dan bantuan keuangan sebesar Rp. 36.353.214.470,00 serta belanja tidak tersangka sebesar Rp. 1.949.155.642,68 yag menurun dari tahun 2004.

Dari rincian Anggaran Pendapatan Belanja Daerah (APBD) kota Malang pada tahun 2005 mengalami defisit, sebesar Rp. 24.345.855.150,52 karena jumlah belanja lebih besar yaitu Rp. 435.828.127.202,52 jika dibandingkan dengan jumlah pendapatan Rp. 411.482.272.051,00. Oleh karena itu, Pemerintah Kota Malang harus lebih meningkatkan pendapatan daerahnya agar Anggaran Pendapatan dan Belanja Daerah (APBD) tidak defisit.

Realisasi Anggaran Pendapatan Belanja Daerah (APBD) kota Malang pada tahun 2006, Pada sisi penerimaan daerah yang terdiri dari Pendapatan Asli Daerah (PAD) sebesar Rp. 59.990.746.371,50, menurun dari tahun 2005, yang terdiri dari pajak daerah, retribusi daerah, hasil pnegelolaan kekayaan daerah yang dipisahkan dan lain-lain pendapatan yang sah. Dalam hal ini pajak daerah mempunyai nilai tertinggi yaitu sebesar Rp. 30.871.262.802,50, yang meningkat dari tahun 2004 dan 2005. Retribusi daerah sebesar Rp. 18.836.834.980,00. pajak daerah merupakan nilai yang tertinggi dalam peningkatan Pendapatan Asi Daerah (PAD) karena kota Malang merupakan kota yang banyak mempunyai hotel, restoran dan lain-lain. Adapun pajak daerah Kota Malang diperoleh dari pajak hotel, pajak restoran, pajak reklame, pajak penerangan jalan umum. Sedangkan nilai dari hasil perusahaan daerah sebesar Rp. 6.468.648.589,00 dan lain-lain pendapatan asli daerah yang sah sebesar Rp. 3.814.000.000,00 yang mengalami penurunan dari tahun 2005 sebesar Rp. 7.337.500.000,00 turun menjadi $\mathrm{Rp}$. 3.814.000.000,00 pada tahun 2006. Penurunan lain-lain pendapatan yang sah inilah yang mengakibatkan Pendapatan Asli Daerah (PAD) pada tahun 2006 turun sebesar Rp. 74.169.128,5 dari tahun 2005.

Dari sisi Dana Perimbangan, mempunyai nilai sebesar Rp. 473.837.920.719,00 yang terdiri dari bagi hasil pajak, bagi hasil bukan pajak, Dana Alokasi Umum (DAU), dan Dana Alokasi Khusus (DAK). Dana Alokasi Umum (DAU) Kota Malang masih tinggi yaitu sebesar Rp. 367.435.000.000,00 jika dibandingkan dengan dan Dana Alokasi Khusus (DAK) yang nilainya sangat kecil yaitu sebesar Rp. 20.860.000.000,00. Sedangkan transaksi pada Bagi Hasil Pajak atau Bagi Hasil Bukan Pajak (BHPBP) yang mempunyai nilai Rp. 42.886.400.469,00 dan Bagi Hasil Pajak dan Bantuan Keuangan dari Propinsi sebesar Rp. 42.656.520.250,00.

Pada pos belanja daerah dibedakan menjadi dua, yaitu: Belanja Aparatur daerah dan Belanja Publik. Belanja aparatur daerah terdiri dari belanja administrasi umum sebesar Rp. 130.790.697.684,56, belanja operasi dan pemeliharaan sebesar Rp. 15.797.621.770,00, belanja modal sebesar Rp. 5.818.297.000,00. Sedangkan Belanja Publik terdiri dari: belanja administrasi umum sebesar Rp. 163.484.024.028,37, belanja operasi dan pemeliharaan sebesar Rp. 99.211.469.776,20, belanja modal sebesar Rp. 86.744.593.675,00 yang meningkat dari tahun 2004 dan 2005, karena pada tahun 2006 ini ada 
penambahan Belanja Modal Barang Bercorak Kesenian dan Kebudayaan dan Belanja Modal Hewan, Ternak serta Tanaman yang pada tahun 2004 tidak ada, serta penambahan yang pada tahun 2005 tidak ada yaitu; Belanja Modal Alat-alat Teknik/Laboratorium, Belanja Modal Alat-alat Persenjataan/Keamanan dan Belanja Modal Fasilitas Gedung. Belanja bagi hasil dan bantuan keuangan sebesar Rp. 41.694.180.000,00 serta belanja tidak tersangka sebesar Rp. 1.017.984.569,60.

Dari rincian Anggaran Pendapatan Belanja Daerah (APBD) kota Malang pada tahun 2006 mengalami surplus, sebesar Rp. 70.024.708.586,77, dikarenakan pada tahun 2006 ini Lainlain pendapatan yang sah meningkat dari tahun-tahun sebelumnya (2004-2005) dan jumlah belanja lebih kecil yaitu Rp. 544.558.868,73 dari jumlah pendapatan yang mencapai nilai sebesar $\mathrm{Rp}$. 614.583.577.090,50. Pemerintah Kota Malang pada tahun 2006 ini telah bisa enutupi defisit pada tahun-tahun sebelumnya yang Anggaran belanja Daerahnya mengalami defisit.

Realisasi Anggaran Pendapatan Belanja Daerah (APBD) kota Malang pada tahun 2007, model susunan berbeda dengan tahun-tahun sebelumnya, yaitu tahun 2004-2006, sesuai dengan Peraturan Daerah Kota malang nomor 7 Tahun 2007. Pada sisi penerimaan daerah yang terdiri dari Pendapatan Asli Daerah (PAD) sebesar Rp. 82.875.966.418,00, yang terdiri dari pajak daerah, retribusi daerah, hasil pnegelolaan kekayaan daerah yang dipisahkan dan lain-lain pendapatan yang sah. Dalam hal ini pajak daerah mempunyai nilai tertinggi yaitu sebesar Rp. 37.509.729.844,00. Retribusi daerah sebesar Rp. 22.331.705.025,00. Pajak daerah merupakan nilai yang tertinggi dalam peningkatan Pendapatan Asi Daerah (PAD) karena kota Malang merupakan kota yang banyak mempunyai hotel, restoran dan lain-lain. Adapun pajak daerah Kota Malang diperoleh dari pajak hotel, pajak restoran, pajak reklame, pajak penerangan jalan umum. Sedangkan nilai dari hasil perusahaan daerah sebesar Rp. 6.748.093.089,00 dan lain-lain pendapatan asli daerah yang sah sebesar Rp. 16.286.438.460,00.

Dari sisi Dana Perimbangan, mempunyai nilai sebesar Rp. 488.740.697.669,00 yang terdiri dari bagi hasil pajak, bagi hasil bukan pajak, Dana Alokasi Umum (DAU), dan Dana Alokasi Khusus (DAK). Dana Alokasi Umum (DAU) Kota Malang masih tinggi yaitu sebesar Rp. 417.300.000.000,00 jika dibandingkan dengan dan Dana Alokasi Khusus (DAK) yang nilainya sangat kecil yaitu sebesar Rp. 26.934.000.000,00. Sedangkan transaksi pada Bagi Hasil Pajak atau Bagi Hasil Bukan Pajak (BHPBP) yang mempunyai nilai Rp. 44.506.697.669,00.

Pada pos belanja daerah terdiri dari belanja langsung dan belanja tidak langsung. Belanja langsung sebesar Rp. 291.143.786.431,63 terdiri dari belanja pegawai, belanja bunga, belanja subsidi, belanja hibah, belanja bantuan sosial, belanja bagi hasil kepada pemerintahan daerah, belanja bantuan keuangan kepada pmerintahan daerah, dan belanja tak terduga. Belanja pegawai merupakan belanja yang terbesar, yaitu Rp. 252.267.729.953,63 belanja bunga $\mathrm{Rp}$. 1.065.030.000,00 yang pada tahun 20042006 tidak adanya transaksinya. Pada tahun 2007 ini tidak terjadi transaksi Belanja Subsidi dan Belanja Hibah. Belanja bagi hasil kepada pemerintah daerah sebesar Rp. 100.000.000,00, dan belanja tidak terduga sebesar Rp. 2.661.921.978,00. sedangakan Belanja Langsung sebesar Rp. 358.808.731.526,92 yang terdiri dari; 
belanja pegawai sebesar Rp. 67.670.654.395,00, belanja barang dan jasa Rp. 139.853.154.470,39 dan belanja modal sebesar Rp. 151.284.922.661,53.

Realisasi Anggaran Pendapatan Belanja Daerah (APBD) kota Malang pada tahun 2008, model susunan sama dengan tahun 2007. Pada sisi penerimaan daerah yang terdiri dari Pendapatan Asli Daerah (PAD) sebesar Rp. 82.213.442.771,93, yang terdiri dari pajak daerah, retribusi daerah, hasil pnegelolaan kekayaan daerah yang dipisahkan dan lain-lain pendapatan yang sah. Dalam hal ini pajak daerah mempunyai nilai tertinggi yaitu sebesar Rp. 42.112.940.638,00. Retribusi daerah sebesar Rp. 22.345.419.970,00. Pajak daerah merupakan nilai yang tertinggi dalam peningkatan Pendapatan Asi Daerah (PAD) karena kota Malang merupakan kota yang banyak mempunyai hotel, restoran dan lain-lain. Adapun pajak daerah Kota Malang diperoleh dari pajak hotel, pajak restoran, pajak reklame, pajak penerangan jalan umum. Sedangkan nilai dari hasil perusahaan daerah sebesar Rp. 9.408.328.703,60 dan lain-lain pendapatan asli daerah yang sah sebesar Rp. 8.346.753.460,33.

Dari sisi Dana Perimbangan, mempunyai nilai sebesar Rp. 566.486.946.439,00 yang terdiri dari bagi hasil pajak, bagi hasil bukan pajak, Dana Alokasi Umum (DAU), dan Dana Alokasi Khusus (DAK). Dana Alokasi Umum (DAU) Kota Malang masih tinggi yaitu sebesar Rp. 473.050.489.000,00 jika dibandingkan dengan dan Dana Alokasi Khusus (DAK) yang nilainya sangat kecil yaitu sebesar Rp. 31.782.000.000,00. Sedangkan transaksi pada Bagi Hasil Pajak atau Bagi Hasil Bukan Pajak (BHPBP) yang mempunyai nilai $\mathrm{Rp}$. 61.654.457.439,00. Lain-lain Pendapatan yang Sah sebesar Rp. 59.453.345.282,82 yang terdiri dari pendapatan hibah, dana hibah, (tidak terdapat nilainya) dana bagi hasil pajak dari provinsi dan pemerintah daerah lainnya sebesar Rp. 52.312.366.182,82, dan dana penyesuaian dan otonomi khusus Rp. 7.072.479.100,00 serta bantuan keuangan dari provinsi atau pemerintah daerah lainnya sebesar Rp. 68.500.000,00.

Pada pos belanja daerah terdiri dari belanja langsung dan belanja tidak langsung. Belanja langsung sebesar Rp. 355.915.586.795,16 terdiri dari belanja pegawai, belanja bunga, belanja subsidi, belanja hibah, belanja bantuan sosial, belanja bagi hasil kepada pemerintahan daerah, belanja bantuan keuangan kepada pmerintahan daerah, dan belanja tak terduga. Belanja pegawai merupakan belanja yang terbesar, yaitu Rp. 309.359.398.163,72 belanja bunga $\mathrm{Rp}$. $891.614 .585,36$, yang pada tahun 20042006 tidak adanya transaksinya. Pada tahun 2008 ini tidak terjadi transaksi Belanja Subsidi dan Belanja Hibah sebesar Rp. 29.763.168.500,00, yang pada tahun 2007 tidak ada transaksi. Belanja bantuan sosial sebesar Rp. 13.202.100.000,00 Belanja bagi hasil kepada pemerintah daerah sebesar Rp. 100.000.000,00, dan belanja tidak terduga sebesar Rp. 2.599.305.546,08. Sedangakan Belanja Langsung sebesar Rp. 400.166.164.772,25 yang terdiri dari; belanja pegawai sebesar Rp. 70.346.958.249,00, belanja barang dan jasa Rp. 145.533.048.404,25 dan belanja modal sebesar Rp. 184.286.158.119,00.

Dari rincian Anggaran Pendapatan Belanja Daerah (APBD) kota Malang pada tahun 2008 mengalami defisit, sebesar Rp. 47.928.017.073,66, karena jumlah belanja lebih besar yaitu $\mathrm{Rp}$. 756.081.751.567,41 jika dibandingkan dengan jumlah pendapatan sebesar Rp. 708.153.734.493,75. 
Tabel 1. Kontribusi pos-pos penerimaan Pendapatan Asli Daerah (PAD) di Kota Malang Periode tahun 2004-2008

\begin{tabular}{cccccc}
\hline \multirow{2}{*}{ Tahun } & Pajak Daerah & \multirow{2}{*}{ Retribusi Daerah } & BUMD & $\begin{array}{c}\text { Pendapatan lain-lain } \\
\text { yang sah }\end{array}$ & \multirow{2}{*}{ Total PAD } \\
\hline 2004 & $25.648 .275 .000,00$ & $15.811 .138 .300,00$ & $4.331 .375 .000,00$ & $3.737 .500 .000,00$ & $49.528 .288 .300,00$ \\
2005 & $29.512 .487 .500,00$ & $17.060 .726 .000,00$ & $6.154 .202 .000,00$ & $7.337 .500 .000,00$ & $60.064 .915 .500,00$ \\
2006 & $30.871 .262 .802,50$ & $18.836 .834 .980,00$ & $6.468 .648 .589,00$ & $3.814 .000 .000,00$ & $59.990 .746 .371,50$ \\
2007 & $37.509 .729 .844,00$ & $22.331 .705 .025,00$ & $6.748 .093 .089,00$ & $16.286 .438 .460,00$ & $82.875 .966 .418,00$ \\
2008 & $42.112 .940 .638,00$ & $22.345 .419 .970,00$ & $9.408 .328 .703,60$ & $8.346 .753 .460,33$ & $82.213 .442 .771,93$ \\
Rerata & $33.130 .939 .157,00$ & $19.277 .164 .855,00$ & $6.622 .129 .476,00$ & $7.904 .438 .384,00$ & $66.934 .671 .872,00$ \\
& & & & & \\
\hline
\end{tabular}

Sumber: Sekretariat Daerah Kota Malang Bagian keuangan

Oleh karena itu, Pemerintah Kota Malang harus lebih meningkatkan pendapatan daerahnya agar Anggaran Pendapatan dan Belanja Daerah (APBD) tidak defisit.

Pada tabel 1 di atas, dapat dilihat bahwa realisasi pendapatan asli daerah Kota Malang, jumlah terbesar yang diterima adalah dari pajak daerah. Sedangkan pendapatan atau penerimaan lain-lain daerah masih relatif kecil dalam meningkatkan pendapatan asli daerah. Pajak daerah merupakan pajak yang dikelola oleh pemerintah daerah, baik provinsi maupun kabupaten/kota yang berguna untuk menunjang penerimaaan Pendapatan Asli Daerah (PAD) dan hasil penerimaan tersebut masuk dalam Anggaran Pendapatan dan Belanja Daerah (APBD).

Dari tabel 1 dapat diketahui bahwa dari masing-masing sektor Pendapatan Asli Daerah terhadap Total Pendapatan Asli Daerah dan rata-rata sumbangannya di Kota Malang menunjukkan sektor pajak daerah mengalami peningkatan dari tahun 2004 sebesar Rp. 25.648.275.000,00 hingga 2008 mencapai Rp. 42.112.940.638,00, dengan rata-rata Rp. 33.130.939.157,00. Retribusi Daerah juga mengalami kenaikan dari tahun 2004 sebesar Rp. 15.811.138.300,00 hingga tahun 2008 mencapai Rp. 22.345.419.970,00, dengan rata-rata Rp. 19.277.164.855,00. Pendapatan lain-lain juga memiliki kontribusi yang relatif tinggi, rata-rata sebesar Rp. 7.904.438.384,00 jika dibandingkan dengan BUMD yang rataratanya lebih rendah, yaitu sebesar $\mathrm{Rp}$. 6.622.129.476,00. Hal ini menunjukkan sumber utama bagi Pendapatan Asli Daerah (PAD) Kota Malang adalah berpedoman pada ketiga sektor tersebut yaitu pajak daerah, retribusi daerah, dan pendapatan lain-lain. Sedangkan sektor BUMD masih belum memberikan kontribusi yang memadai bagi Pendapatan Asli Daerah (PAD).

Selama kurun waktu lima tahun terakhir (2004-2008) BUMD lebih kecil dibandingkan pajak daerah, retribusi daerah dan pendapatan lain-lain dengan rata-rata sebesar Rp. 6.622.129.476,00. Tampak pula bahwa kontribusi pajak daerah relatif lebih tinggi dibanding pospos penerimaan PAD yang lain yaitu rata-ratanya sebesar Rp. 33.130.939.157,00. Retribusi daerah terletak pada urutan kedua setelah pajak daerah dengan rata-rata sebesar Rp. 19.277.164.855,00. Selanjutnya Pendapatan Lain-lain rata-ratanya sebesar Rp. 7.904.438.384,00.

Peningkatan Pendapatan Asli Daerah (PAD) Kota Malang harus dilakukan oleh pemerintah Kota Malang mengingat bahwa untuk masa ke depan tidak mungkin harus bergantung pada subsidi pusat, meskipun pendapatan asli daerah tidak harus membiayai seluruh anggaran namun Pendapatan Asli Daerah (PAD) merupakan indikator kemandirian dari suatu daerah. 
Dari tabel 2 dapat disimpulkan bahwa perkembangan dana perimbangan terus meningkat dari tahun 2004 sebesar Rp. 277.374.022.985,00 sampai tahun 2008 sebesar Rp. 566.486.946.439,00. Hal ini disebabkan oleh besarnya subsidi pemerintah pusat kepada pemerintahan Kota Malang, dengan rata-rat selam kurun waktu lima tahun (2004-2008) sebesar Rp. 423.292.388.872,80.

Sedangkan jumlah Bagi Hasil Pajak dan Bukan Pajak (BHPBP) juga terus meningkat dari tahun 2004 sebesar Rp. 36.040.755.046,00 hingga pada tahun 2008 sebesar Rp. 61.654.457.439,00, dengan rata-rata $\mathrm{Rp}$. 45.717.811.085,00. Dana Alokasi Khusus dengan Dana Alokasi Umum mengalami kenaikan pada setiap tahunnya dari tahun 2004 sebesar Rp. 217.128.000.000 sampai pada tahun 2008 sebesar Rp. 504.832.490.000. dengan rata-rata Rp. 737.610.297.800,00.

Pada tabel di atas dapat dilihat bahwa realisasi Dana Perimbangan Kota Malang, jumlah terbesar yang diterima adalah dari Dana Alokasi Umum (DAU). Sedangkan Dana Alokasi Khusus (DAU) masih relatif kecil. Dana Alokasi Khusus (DAU) merupakan dana yang bersumber dari pendapatan Anggaran Pendapatan Belanja Negara (APBN) yang dialokasikan kepada daerah berdasarkan angka persentase untuk menandai kebutuhan daerah dalam rangka pelaksanaan desentralisasi.

Tabel 2. Kontribusi Dana Perimbangan Daerah di Kota Malang Periode tahun 2004-2008

\begin{tabular}{rccc}
\hline Tahun & BHPBP & DAU+DAK & Total Dana Perimbangan \\
\hline 2004 & $36.040 .775 .046,00$ & $2.121 .780 .000 .000,00$ & $277.374 .022 .985,00$ \\
2005 & $43.500 .724 .802,00$ & $228.910 .000 .000,00$ & $310.022 .356 .552,00$ \\
2006 & $42.886 .400 .469,00$ & $388.295 .000 .000,00$ & $473.837 .920 .719,00$ \\
2007 & $44.506 .697 .669,00$ & $444.234 .000 .000,00$ & $488.740 .697 .669,00$ \\
2008 & $61.654 .457 .439,00$ & $504.832 .489 .000,00$ & $566.486 .946 .439,00$ \\
Rata-rata & $45.717 .811 .085,00$ & $737.610 .297 .800,00$ & $423.292 .388 .872,80$ \\
\hline
\end{tabular}

Sumber: Sekretariat Daerah Kota Malang Bagian keuangan

Keterangan:

BHPBP : Bagi Hasil Pajak dan Bukan Pajak

DAK : Dana Alokasi Khusus

DAU : Dana Alokasi Umum
Dari tabel 3 di bawah menunjukkan bahwa Pendapatan Asli Daerah (PAD) Kota Malang mengalami kenaikan dan penurunan tiap tahunnya, begitupun dengan prosentasenya. Pada tahun 2007 terjadi kenaikan Pendapatan Asli Daerah (PAD) yang cukup signifikan yaitu sebesar $38,14 \%$, Hal ini dikarenakan pada tahun 2007 terdapat peningkatan lain-lain pendapatan asli daerah yang sah yang meningkat drastis dari tahun 2006, yaitu Rp. 3.814.000.000,00 tahun 2006, sedangkan pada tahun 2007 sebesar Rp. 16.286.438.460,00. Namun pada tahun 2006 prosentase kenaikan Pendapatan Asli Daerah (PAD) menurun sangat drastis hingga mencapai nilai negatif sebesar $-0,12$.

Hal ini dikarenakan karena Pendapatan asli Daerah (PAD) menurun nilainya jika dibandingkan dengan tahun 2005 dari Lain-lain pendapatan asli daerah yang sah, pada tahun 2005 sebesar Rp. 7.337.500.000,00 yang menurun di tahun 2006 yaitu Rp. 3.814.000.000,00. Sellain itu, pada tahun 2008 Pendapatan Asli Daerah (PAD) juga mengalami penurunan yang drastis, yaitu $-0,79$, hal ini dikarenakan terjadi penurunan Pendapatan Asli Daerah (PAD) dari tahun 2007. Rata-rata Pendapatan Asli Daerah (PAD) selama kurun waktu lima tahun (2004-2008) sebesar Rp. 66.934.671.872,00 atau $12,06 \%$. 
Tabel 3. Perkembangan Pendapatan Asli Daerah (PAD) Terhadap Total Penerimaan Daerah (TPD) di Kota Malang Periode tahun $2004-2008$

\begin{tabular}{cccccc}
\hline Tahun & PAD & $\%$ & TPD & $\%$ & PAD/TPD $(\%)$ \\
\hline 2004 & $49.528 .288 .300,00$ & - & $339.561 .311 .285,00$ & - & 14,58 \\
2005 & $60.064 .915 .500,00$ & 21,27 & $411.482 .272 .052,00$ & 21,18 & 14,59 \\
2006 & $59.990 .746 .371,50$ & $-0,12$ & $539.712 .457 .090,50$ & 31,16 & 11,11 \\
2007 & $82.875 .966 .418,00$ & 38,14 & $618.754 .836 .128,02$ & 14,64 & 13,39 \\
2008 & $82.213 .442 .771,93$ & $-0,79$ & $708.153 .734 .493,75$ & 14,44 & 11,60 \\
Rata-rata & $66.934 .671 .872,00$ & 12,06 & $523.532 .922 .209,85$ & 16,28 & 13,05 \\
\hline
\end{tabular}

Sumber: Sekretariat Daerah Kota Malang Bagian keuangan

Keterangan :

PAD : Pandapatan Asli Daerah

TPD : Total Penerimaan Daerah

Tahun 2004, kontribusi PAD terhadap TPD sebesar $14,58 \%$. Hal ini dikarenakan adanya peningkatan dari masing-masing kontribusi TPD yaitu Pendapatan Asli Daerah (PAD), dana perimbangan dan subsidi pusat (Dana Alokasi Umum dan Dana Alokasi Khusus). Tahun 2006 prosentase kenaikan TPD cukup baik sebesar $31,16 \%$, namun kontribusi PAD terhadap TPDnya hanya $11,11 \%$ saja. Prosentase kenaikan TPD terjadi kenaikan dan penurunan yang tidak stabil pada tiap tahunnya. Pada tahun 2006 prosentase naik sebesar $31,16 \%$, ha ini dikarenakan adanya peningkatan PAD dan dana perimbangan. Namun pada tahun 2008 terjadi penurunan sebesar 14,44\% yang dikarenakan terjadi penurunan Pendapatan Asli Daerah (PAD). Rata-rata Total Penerimaan Daerah selama lima tahun (2004-2005) sebesar Rp. 523.532.922.209,85 atau sebesar 16,28\%. Sedangkan rata-rata kontribusi PAD terhadap TPD sebesar $13,05 \%$.

Tabel 3 berikut ini akan memperlihatkan perkembangan Bagi Hasil Pajak dan Bukan Pajak (BHPBP) terhadap Total Penerimaan Daerah (TPD) di Kota Malang pada tahun anggaran 2004 -2008

Dari tabel 3 menunjukkan bahwa Bagi Hasil Pajak dan Bukan Pajak (BHPBP) Kota Malang mengalami kenaikan dan penurunan dari tahun 2004-2008. Prosentase kenaikan BHPBP dari tahun ke tahun mengalami kenaikan dan penurunan. Pada tahun 2008 terjadi kenaikan BHPBP yang cukup signifikan yaitu sebesar 38,52\%. Hal ini dikarenakan pada tahun 2008 terdapat kenaikan nilai Bagi Hasil Pajak dan Bukan Pajak (BHPBP) dari tahun 20042007. Rata-rata Bagi Hasil Pajak dan Bukan Pajak (BHPBP) selama kurun waktu lima tahun (2004-2008) sebesar Rp. 45.717.811.085,00 atau $18,87 \%$.

Tahun 2004, kontribusi BHPBP terhadap TPD sebesar $10,61 \%$. Hal ini dikarenakan adanya peningkatan dari masing-masing kontribusi BHPBP yaitu Pajak Bumi dan Bangunan (PBB), Bea perolehan hak atas tanah dan bangunan, bagi hasil pajak penghasilan, pajak bahan bakar kendaraan bermotor, Pajak kendaraan bermotor, pajak pemanfaatan air bawah tanah dan air permukaan, iuran hasil hutan, iuran hak pengusahaan hutan, royalty, perikanan, minyak dan gas, serta pemberian hak atas tanah Negara.

Prosentase kenaikan BHPBP mengalami kenaikan dan penurunan, bahkan pada tahun 2006 turun drastis hingga mencapai nilai yang negatif sebesar $-1,41 \%$. Hal ini dikarenakan adanya penurunan sektor kontribusi masing-masing pada BHPBP. Kontribusi BHPBP pada kurun waktu lima tahun 
(2004-2008) mengalami penurunan, meskipun pada tahun 2008 mengalami kenaikan sebesar 38,52. Rata-rata kontribusi BHPBP terhadap TPD sebesar $9,00 \%$.

Tabel 4 akan memperlihatkan perkembangan Sumbangan Daerah (SD) terhadap Total Penerimaan Daerah (TPD) di Kota Malang pada tahun anggaran 2004 -2008.

Dari tabel 4 menunjukan bahwa Sumbangan Daerah Kota Malang mengalami kenaikan dan penurunan tiap tahunnya. Pada tahun 2005 terjadi kenaikan SD yang sangat besar yaitu 227,00\%, sedangkan pada tahun 2007 terjadi penurunan yang sangat drastis yang mencapai nilai negatif, yang berarti sumbangan daerah mengalami penurunan sebesar -41,62. Rata-rata Sumbangan Daerah selama kurun waktu lima tahun (2004-2005) sebesar Rp.33.305.861.464,76 atau 77,95\%. Sedangkan kontribusi Sumbangan Daerah (SD) terhadap Total Penerimaan Daerah (TPD) mengalami peningkatan yang besar pada tahun 2006 dibanding tahun-tahun lainnya, yaitu sebesar $14,96 \%$ dan mengalami penurunan pada tahun 2004 sebesar 3,72\%. Rata-rata kontribusi SD terhadap TPD sebesar $8,94 \%$.

Tabel 4. Perkembangan Bagi Hasil Pajak dan Bukan Pajak (BHPBP) Terhadap Total Penerimaan Daerah (TPD) di Kota Malang Periode tahun 2004 - 2008

\begin{tabular}{cccccc}
\hline Tahun & \multirow{2}{*}{ BHPBP } & $\%$ & TPD & $\%$ & $\begin{array}{c}\text { BHPBP/TPD } \\
(\%)\end{array}$ \\
\hline 2004 & $36.040 .775 .046,00$ & - & $339.561 .311 .285,00$ & - & 10,61 \\
2005 & $43.500 .724 .802,00$ & 20,69 & $411.482 .272 .052,00$ & 21,18 & 10,57 \\
2006 & $42.886 .400 .469,00$ & $-1,41$ & $539.712 .457 .090,50$ & 31,16 & 7,94 \\
2007 & $44.506 .697 .669,00$ & 33,77 & $618.754 .836 .128,02$ & 14,64 & 7,19 \\
2008 & $61.654 .457 .439,00$ & 38,52 & $708.153 .734 .493,75$ & 14,44 & 8,70 \\
Rata-rata & $45.717 .811 .085,00$ & 18,87 & $523.532 .922 .209,85$ & 16,28 & 9,00 \\
\hline
\end{tabular}

Sumber: Sekretariat Daerah Kota Malang Bagian keuangan

Keterangan :

BHPBP : Bagi Hasil Pajak dan Bukan Pajak

TPD : Total Penerimaan Daerah desentralisasi fiskal dari masing-masing sektor, dapat disimpulkan derajat desentralisasi Kota Malang masih kecil, sehingga dapat dikatakan bahwa Kota Malang masih belum mandiri. Hal ini dikarenakan gaji pegawai masuk pada bagian atau pos belanja daerah, sehingga Pendapatan Asli Daerah Kota Malang yang kecil tidak mampu membiayai gaji pegawai yang sangat besar, selain itu, desentralisasi fiskal masih belum sepenuhnya diserahkan oleh pemerintah pusat kepada pemerintah Kota Malang, contohnya pendapatan daerah Kota Malang masih ditarik oleh pusat, seperti pajak kendaraan bermotor yang nilainya cuku tinggi, pemerintah Kota Malang tidak menerimanya, pajak yang diterima Kota Malang hanya pajak hotel, pajak restoran, pajak reklame, dan pajak penerangan jalan umum. Kebutuhan gaji pegawai yang sangat besar, dan Kota Malang tidak bisa hanya mengandalkan Pendapatan Asli Daerah (PAD) saja, dan bantuan pemerintah unutk memenuhi gaji pegawai tersebut menjadikan Kota Malang belum mandiri. 
Tabel 5. Perkembangan Sumbangan Daerah (SD) Terhadap Total Penerimaan Daerah (TPD) di Kota Malang Periode tahun 2004 - 2008

\begin{tabular}{cccccc}
\hline Tahun & SD & $\boldsymbol{\%}$ & TPD & $\boldsymbol{\%}$ & $\begin{array}{c}\text { SD/TPD } \\
(\boldsymbol{\%})\end{array}$ \\
\hline 2004 & $12.659 .000 .000,00$ & - & $339.561 .311 .285,00$ & - & 3,72 \\
2005 & $41.395 .000 .000,00$ & 227,00 & $411.482 .272 .052,00$ & 21,18 & 10,05 \\
2006 & $80.754 .910 .000,00$ & 95,05 & $539.712 .457 .090,50$ & 31,16 & 14,96 \\
2007 & $47.138 .172 .041,02$ & $-41,62$ & $618.754 .836 .128,02$ & 14,64 & 7,61 \\
2008 & $59.453 .345 .282,82$ & 26,12 & $708.153 .734 .493,75$ & 14,44 & 8,39 \\
Rata-rata & $33.305 .861 .464,76$ & 77,95 & $523.532 .922 .209,85$ & 16,28 & 8,94 \\
\hline
\end{tabular}

Sumber: Sekretariat Daerah Kota Malang Bagian keuangan

Keterangan :

SD : Sumbangan Daerah

TPD : Total Penerimaan Daerah

\section{PENUTUP}

Berdasarkan hasil analisa permasalahan yang telah diuraikan pada bab-bab sebelumnya, maka kesimpulan yang dapat diambil adalah: Berdasarkan perhitungan derajat desentralisasi fiskal Kota Malang yang dihitung dari proporsi Pendapatan Asli Daerah (PAD) terhadap Total Penerimaan Daerah (TPD) ratarata selama kurun waktu lima tahun (2004 s/d 2008) sebesar 13,05\%. Sedangkan proporsi Bagi Hasil Pajak dan Bukan Pajak (BHPBP) terhadap Total Penerimaan Daerah (TPD) sebesar 9,00\%. Proporsi sumbangan (SD) daerah terhadap Total Penerimaan Daerah (TPD) dalam kurun waktu lima tahun (2004 s/d 2008) sebesar 8,94\%. Hal ini menunjukkan bahwa ketergantungan pemerintah Kota Malang terhadap pemerintah pusat sangat besar atau dapat dikatakan bahwa desentralisasi fiskal Kota Malang masih tinggi, atau dapat dikatakan bahwa Kota Malang belum mandiri, karena besarnya bantuan pemerintah pusat untuk membiayai belanja daerah Kota Malang yang tidak bisa dibiayai melalui Pendapatan Asli Daerah (PAD) saja.

\section{DAFTAR PUSTAKA}

Bird Richard, 2000, Desentralisasi Fiskal di Negara-Negara Berkembang; PT. Gramedia Pustaka Utama, Jakarta.

Geografi Kota Malang Online, (http://www.pemkotmalang.go.id), diakses 2009.

Halim, Abdul, 2004, Bunga Rampai: Manajemen Keuangan Daerah, Edisi Revisi, (UPP) AMP YKNPN, Yogyakarta.

Makmum, Potret Perekonomian Daerah Sebelum dan Era Desentralisasi Fiskal, http://fiskalDepartemenKeuangan. go.id/webbkf/kajian\%5co9/POTR U\%20PEREKONOMIAN\%20DA ERAHmakmun.pdf.

Mardiasmo, 2002, Otonomi dan Manajemen Keuangan Daerah, Andi Yogyakarta, Yogyakarta.

Marshita, Prima, Desentralisasi FiskalBerhasilkan Memeratakan 
Pendapatan?.

http://Patriotika.multiply.com/jour nal/item/48.html. 16 Maret 2009.

Muluk, Khairul M.R, 2007, Desentralisasi dan Pemerintahan Daerah, Edisi Pertama, Bayumedia Publishing, Malang Jawa Timur.

Muluk, Kahirul, Apakah Metodologi Penelitian (Bagi) Administrasi Publik.

http://publik.brawijaya.ac.id/?hlm= jedlist\&ed=1157043600\&edid $=11$ 45934741. 16 Maret 2009

Mulyana, Budi, 2006, Keuangan Daerah Perspektif Desentralisasi Fiskal dan Pengelolaan APBD di Indonesia, Lembaga Pengkajian Keuangan Publik dan Akuntansi Pemerintah (LPKPAP) dan Badan Pendidikan dan Pelatihan Keuangan (BPPK), Jakarta Selatan.

Otonomi Daerah: alat konglomerasi, 2008, (http://www.jurnalekonomi.org/), diakses 2009.

Pheni, Chalid, 2005, Keuangan Daerah Investasi, dan Desentralisasi Tantangan dan Hambatan, PT. Percetakan Penebar Swadaya, Jakarta.

Prospek Otonomi Daerah di Masa Mendatang, 2006, (http://www.APKASI.go.id), diakses 2009.

Realisasi Anggaran Pendapatan dan Belanja Daerah (APBD), 20002006, (http://www.djpkpd.or.id), Diakses 2008.
Rudy, 2008, Desentralisasi Indonesia: Memupuk Demokrasi dan Penciptaan Tata pemerintahan. Rentboy.www.multiply.com/journ $\mathrm{al} / \mathrm{item} / 10$.

Sekretariat Daerah Kota Malang Bagian Keuangan, Laporan Realisasi Anggaran Pendapatan dan Belanja Daerah (APBD) Tahun 2004-2008.

The Indonesian Society for transparency (Masyarakat Transparansi Indonesia), 1999, Pengertian (Definisi Otonomi Daerah online), (http://www.transparansi.or.id), diakses, 2009. 